\title{
Inhibition of matrix metalloproteinases reduces ischemia-reperfusion acute kidney injury
}

\author{
Shinobu Kunugi ${ }^{1}$, Akira Shimizu', Naomi Kuwahara ${ }^{1}$, Xuanyi Du', Mikiko Takahashi ${ }^{1}$, Yasuhiro Terasaki ${ }^{1}$, \\ Emiko Fujita ${ }^{1}$, Akiko Mii ${ }^{1}$, Shinya Nagasaka ${ }^{1}$, Toshio Akimoto ${ }^{2}$, Yukinari Masuda' ${ }^{1}$ and Yuh Fukuda ${ }^{1}$
}

Matrix metalloproteinases (MMPs) are endopeptidases that degrade extracellular matrix and involved in ischemic organ injuries. The present study was designed to determine the role of MMP-2 in the development of ischemic acute kidney injury (AKI). AKI was induced in MMP-2 wild-type (MMP-2 ${ }^{+/+}$) mice by $30,60,90$, and 120 min renal ischemia and reperfusion. Renal histology, expression and activity of MMP-2 and MMP-9, and renal function were examined during the development of AKI. AKI was also induced in MMP-2-deficient (MMP-2 ${ }^{-/-}$) mice and MMP-2 ${ }^{+/+}$mice treated with inhibitor of MMPs (minocycline and synthetic peptide MMP inhibitor). In MMP-2 ${ }^{+/+}$mice, MMP-2 and MMP-9 activities increased significantly at 2 to $24 \mathrm{~h}$, peaked at $6 \mathrm{~h}$, after reperfusion. Immunohistochemical analysis identified MMP-2 in the interstitium around tubules and peritubular capillaries in the outer medulla. Acute tubular injury (ATI), including apoptosis and necrosis, was evident in the outer medulla at $24 \mathrm{~h}$, along with renal dysfunction. As ischemia period increases, MMP-2 and MMP-9 activities at $6 \mathrm{~h}$ and severity of AKI at $24 \mathrm{~h}$ increased depending on the duration of ischemia between 30 and $120 \mathrm{~min}$. However, the kidneys of MMP- $2^{-/-}$mice showed minimal ATl; serum creatinine $24 \mathrm{~h}$ after reperfusion was significantly low in these mice. Inhibitors of MMPs reduced ATI and improved renal dysfunction at $24 \mathrm{~h}$. We conclude that MMPs, especially MMP-2 have a pathogenic role in ischemiareperfusion AKI, and that inhibitors of MMPs can protect against ischemic AKI.

Laboratory Investigation (2011) 91, 170-180; doi:10.1038/labinvest.2010.174; published online 18 October 2010

KEYWORDS: acute kidney injury; acute tubular injury; ischemia/reperfusion; MMP-2; MMP-9; MMP inhibitor

Ischemia-reperfusion acute kidney injury (AKI) remains a major cause of morbidity and mortality. ${ }^{1-5}$ The pathophysiology of AKI is complex; the initial ischemia and reperfusion events rapidly lead to energy loss, which ultimately triggers a wide and intricately linked cascade of tubular epithelial cell death pathways. Over the past decade, various molecular mechanisms have been implicated, including activation of $\mathrm{Ca}^{2+}$-dependent proteases or other enzymes, oxidative stress, and even programmed cell death signals, such as apoptosis. ${ }^{6-8}$ In addition to these primarily intracellular events, evidence for the importance of intercellular signaling is beginning to emerge, all cells in the renal tubular and microvasculature are also affected, not just tubular epithelial cells. ${ }^{6-10}$ Renal tubulovascular perturbations in AKI lead to tubular damage, back leak, obstructive cast formation, leukocyte infiltration, and altered renal microvascular function that contribute to the development of AKI over hours or days after ischemia-reperfusion.

Matrix metalloproteinases (MMPs) are a family of zinc-dependent proteases responsible for extracellular matrix turnover, as well as degradation of bioactive proteins. ${ }^{11,12}$ This family includes collagenases, gelatinases, stromelysins, and membranetype MMPs. Recently, MMPs, especially gelatinases (MMP-2 and MMP-9) have been demonstrated to have major roles in the pathophysiology of ischemia-reperfusion injury in several organs, including the central nervous system, heart, liver, lung, and other tissues. ${ }^{13-20}$ In the kidney, several studies have demonstrated that MMP-2 and MMP-9 are upregulated after ischemia-reperfusion, and that MMP activation modulates renal microvascular permeability. ${ }^{21-24}$ However, the role of MMPs during the development of AKI is still uncertain, because contradictory results have been reported by several studies. ${ }^{25-27}$

The present study was designed to determine whether MMP-2 and MMP-9 are activated during the development of ischemic AKI. After demonstrating this to be the case, experiments were then performed to determine the therapeutic effect of inhibition of MMP activity on ischemic AKI using MMP-2 knockout mice, minocycline, and a synthetic peptide MMP-2/MMP-9 inhibitor, in reducing the development of ischemic AKI.

'Department of Analytic Human Pathology, Nippon Medical School, Tokyo, Japan and ²Division of Laboratory Animal Science, Nippon Medical School, Tokyo, Japan Correspondence: Dr A Shimizu, MD, PhD, Department of Analytic Human Pathology, Nippon Medical School, 1-1-5, Sendagi, Bunkyo-ku, Tokyo 113-8602, Japan. E-mail: ashimizu@nms.ac.jp 


\section{MATERIALS AND METHODS Mice}

Gelatinase A (MMP-2) knockout (MMP-2 ${ }^{-1-}$ ) mice were generated by gene targeting, ${ }^{28}$ and $\mathrm{MMP}-2^{-1-}$ mice generated in $\mathrm{C} 57 \mathrm{BL} / 6$ genetic background were kindly provided by Shigeyoshi Itohara (Laboratory for Behavioral Genetics, RIKEN Brain Science Institute, Saitama, Japan). Mice were used at 3 to 4 months of age. All experimental procedures described here were approved by the Nippon Medical School Animal Studies Committee.

\section{Renal Ischemia-Reperfusion Model}

We performed three experiments using $\mathrm{MMP}-2^{+/+}$and MMP-2 $2^{-1-}$ mice. In experiment 1 , AKI was induced in MMP- $2^{+/+}$mice by $30,60,90$, or 120 min of ischemia using complete occlusion of both renal arteries by Sugita aneurysmal clips (Mizuho Ikakogyo, Tokyo, Japan). The mice were anesthetized with intraperitoneal (IP) pentobarbital sodium $(40-70 \mathrm{mg} / \mathrm{kg})$ and placed on a homeothermic table to maintain their body temperature at $37^{\circ} \mathrm{C}$. After reperfusion, the mice ( $n=5$ at each time point) were killed at $0,2,6,12$, and $24 \mathrm{~h}$ after reperfusion. In experiment 2 , AKI was induced in $\mathrm{MMP}-2^{-/-}$mice by $60 \mathrm{~min}$ ischemia. After reperfusion, mice ( $n=5$ at each time point) were sacrificed at $0,2,6,12$, or $24 \mathrm{~h}$. In experiment $3, \mathrm{MMP}-2^{+/+}$mice with $60 \mathrm{~min}$ ischemia-reperfusion received minocycline (Sigma, St Louis, MO, USA) or synthetic peptide MMPs inhibitor (MMP-2/ MMP-9 Inhibitor III, Calbiochem, Germany) from $36 \mathrm{~h}$ before renal ischemia to $24 \mathrm{~h}$ after reperfusion. Minocycline $45 \mathrm{mg} / \mathrm{kg}$ in dimethyl sulfoxide and $0.9 \% \mathrm{NaCl}$ or an equal volume of dimethyl sulfoxide and $0.9 \% \mathrm{NaCl}$ (placebo) was injected IP. This was administered $36 \mathrm{~h}$ before renal ischemia and was followed by $22.5 \mathrm{mg} / \mathrm{kg}$ IP every $12 \mathrm{~h}$ for a total of six doses, based on previously established protocols. ${ }^{22,29}$ The synthetic peptide MMP-2/MMP-9 inhibitor III $2.5 \mathrm{mg} / \mathrm{kg}$ in $0.9 \% \mathrm{NaCl}$ or an equal volume of $0.9 \% \mathrm{NaCl}$ (placebo) was injected IP. This was administered $36 \mathrm{~h}$ before renal ischemia and followed by $2.5 \mathrm{mg} / \mathrm{kg}$ IP every $12 \mathrm{~h}$ for a total of six doses. The dose of MMP-2/MMP-9 Inhibitor III was based on the in vivo anti-cancer therapies reported in the literature. ${ }^{30}$ Mice ( $n=5$ at each time point) treated with minocycline or MMP-2/MMP-9 inhibitor III were killed at $6 \mathrm{~h}$ or $24 \mathrm{~h}$. To assess renal function, blood samples were collected for measurement of plasma creatinine and blood urea nitrogen using an autoanalyzer (SRL, Tokyo, Japan).

Histopathological and Immunohistochemical Examination After removal of the kidney, renal tissues were fixed in $20 \%$ buffered formalin and embedded in paraffin for light microscopy. Tissues were stained with hematoxylin and eosin, periodic acid-Schiff and periodic acid-methenamine Silver for histopathological examination.

The following primary antibodies or Lectin were used for immunohistochemistry. (a) Goat polyclonal anti-MMP-2 antibody (Santa Cruz Biotechnology, Santa Cruz, CA, USA) to detect MMP-2-producing cells. (b) Goat polyclonal anti-TIMP1 (Santa Cruz Biotechnology) to detect cells that express TIMP1. (c) Goat polyclonal anti-TIMP-2 (Santa Cruz Biotechnology) to detect cells that express TIMP-2. (d) Texas red conjugated Lycopersicon esculentum (Tomato) Lectin (Vector Laboratories, Burlingame, CA, USA), which has been used as a marker for endothelial cells and some tubular epithelial cells. ${ }^{31,32}$ For immunohistochemistry, frozen tissue sections were stained by the standard indirect technique, and observed with a fluorescence microscope. To detect MMP-2 expression on peritubular capillary (PTC) endothelial cells, double immunohistochemistry staining with MMP-2 and Tomato Lectin was performed. For this, $4 \mu \mathrm{m}$-thick frozen sections were stained with anti-MMP-2 antibody (goat IgG) and followed by FITC-labeled donkey antigoat IgG antibody (Santa Cruz Biotechnology). Sections were then incubated with Texas-red conjugated Tomato Lectin. We used sections treated without primary antibodies as controls.

In histological sections, fragmented nuclear DNA associated with apoptosis was labeled by the terminal deoxynucleotidyl transferase-mediated dUTP-biotin nick endlabeling (TUNEL) method. ${ }^{33}$

For electron microscopic examination, the kidney tissue was fixed in $2.5 \%$ glutaraldehyde solution in phosphate buffer ( $\mathrm{pH} 7.4$ ) and postfixed with $1 \%$ osmium tetroxide, dehydrated and embedded in Epok 812. Ultrathin sections were stained with uranyl acetate, lead citrate and then examined with an electron microscope (model H7100, Hitachi Corp., Tokyo, Japan).

To examine the severity of ATI, tissue damage was assessed in a blind manner and scored using a tubular damage score according to the percentage of damaged tubules (loss of brush border, tubular dilation, cast formation, and cell lysis); ${ }^{34} 1$, less than 25\% damaged; 2, 25-50\% damaged; 3, $50-75 \%$ damaged; and 4 , more than $75 \%$ damaged. To examine the apoptotic tubular epithelial cells, the number of TUNEL + tubular epithelial cells, which were characterized by the tubular epithelial cells with TUNEL + nuclei, was counted in $\times 400$ high power field. For the tubular damage score and the number of TUNEL + tubular epithelial cells, a total of 40 high power fields in outer medulla from each mouse kidney were examined.

\section{Gelatin Zymography}

As described previously, ${ }^{35}$ supernatants of $10 \mu \mathrm{g}$ of total protein from kidney homogenate from each animal was applied to gelatin zymography. Briefly, electrophoresis was carried out on $10 \%$ polyacrylamide gels containing $0.1 \%$ gelatin under nonreducing conditions. After electrophoresis, the gels were washed in $2.5 \%$ Triton $\mathrm{X}-100$ to remove sodium dodecyl sulfate, incubated for $16 \mathrm{~h}$ at $37^{\circ} \mathrm{C}$, and stained with 0.1\% Coomassie Brilliant Blue R250 (Sigma). Densitometric analysis of the gels was performed using NIH image software (Image, v. 1.62; National Institutes of Health, Bethesda, Maryland). MMP-2 and MMP-9 activity was estimated from their gelatinolytic activities. 


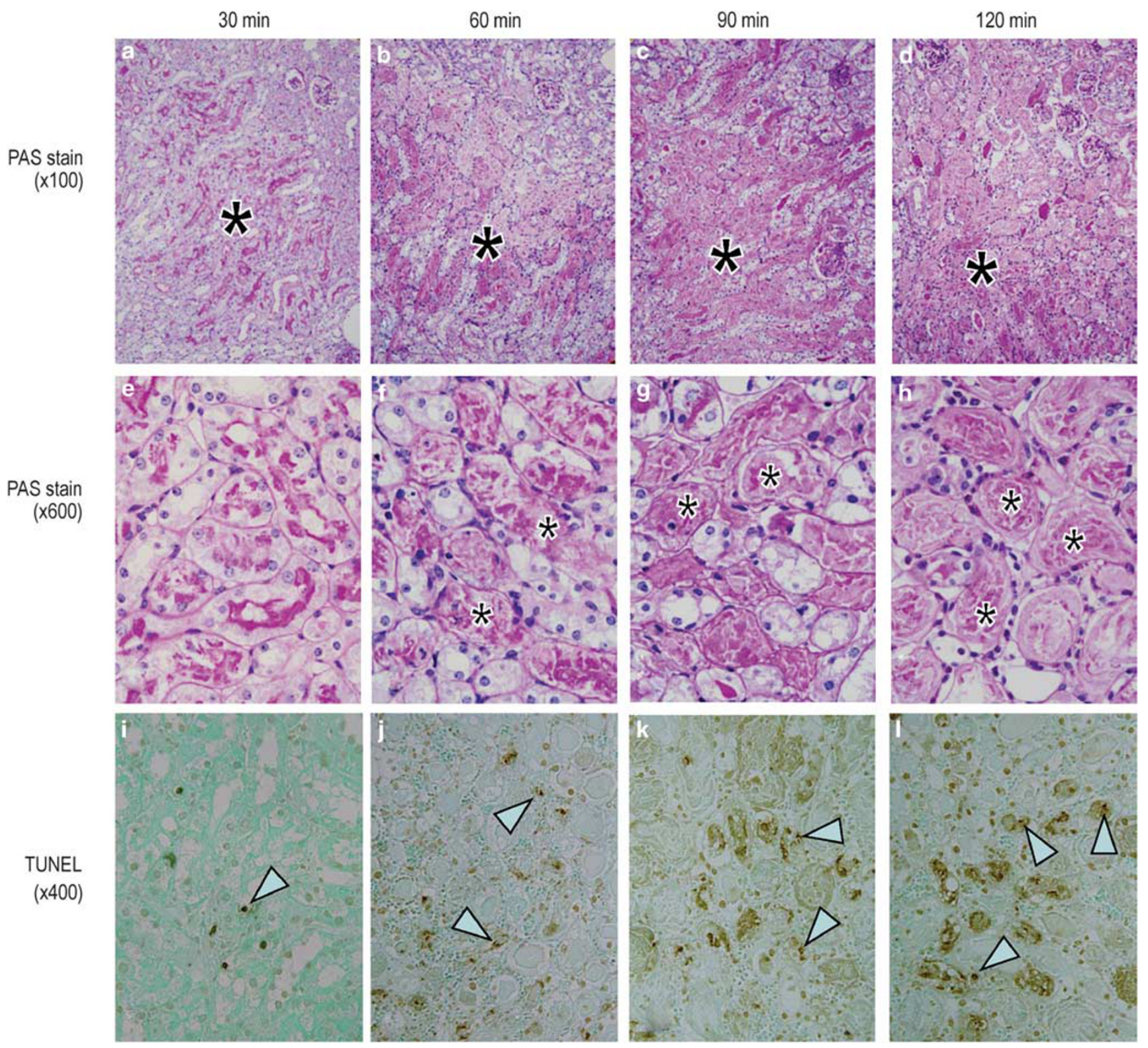

Figure 1 Development of acute tubular injury (ATI) in MMP-2 $2^{+/+}$mice at $24 \mathrm{~h}$ after $30 \mathrm{~min}$ ischemia $(\mathbf{a}, \mathbf{e}, \mathbf{i}), 60 \mathrm{~min}$ ischemia $(\mathbf{b}, \mathbf{f}, \mathbf{j}), 90 \mathrm{~min}$ ischemia $(\mathbf{c}, \mathbf{g}, \mathbf{k})$, and $120 \mathrm{~min}$ ischemia $(\mathbf{d}, \mathbf{h}, \mathbf{l})(\mathbf{a}-\mathbf{d}$ : periodic acid-Schiff (PAS) stain, $\times 100$; e-h: PAS stain, $\times 600 ; \mathbf{i}-\mathbf{l}$ : TUNEL stain, $\times 400)$. ATI developed in the outer stripe of the outer medulla ( ${ }^{*}$ in $\mathbf{a}-\mathbf{d}$ ) in the kidney. Although tubular epithelial cell necrosis was not prominent at $24 \mathrm{~h}$ after $30 \mathrm{~min}$ ischemia, severe tubular epithelial cell necrosis ( ${ }^{*}$ in $\mathbf{f}-\mathbf{h}$ ) developed with TUNEL + dead cells (arrowheads in $\mathbf{i}-\mathbf{l}$ ) at $24 \mathbf{h}$ after 60,90 , and 120 min ischemia.

\section{In situ Zymography}

To examine the localization of gelatinolytic activity in injured kidney, we applied in situ zymography using MMP in situ Zymo-Film (Wako Laboratory Chemicals, Osaka, Japan). MMP in situ Zymo-Film was developed for observation of the enzyme activity of MMPs in tissue specimens, and composed of a $7 \mu \mathrm{m}$-thick layer of special gelatin of a polyester base. Cryostatcut kidney sections (4 to $6 \mu \mathrm{m}$ thickness) were placed on the film, and incubated at $37^{\circ} \mathrm{C}$ for 6 to $32 \mathrm{~h}$ according to the instructions provided by the manufacturer. After incubation, films were stained in biebrich scarlet stain solution (Wako), and observed by light microscopy.

\section{Statistical Analysis}

All data are expressed as mean \pm s.d.. Statistical differences between groups were determined using Student's $t$-test. Significance was defined at $P<0.05$.

\section{RESULTS}

\section{Ischemic AKI in MMP-2 ${ }^{+I+}$ Mice}

We examined the development of ischemic AKI induced by $30,60,90$, and $120 \mathrm{~min}$ ischemia-reperfusion in MMP-2 $2^{+/+}$ mice (Figure 1). At $24 \mathrm{~h}$ after reperfusion, although no apparent acute tubular injury (ATI) developed in the mice with $30 \mathrm{~min}$ ischemia, widespread necrosis of tubular epithelial 


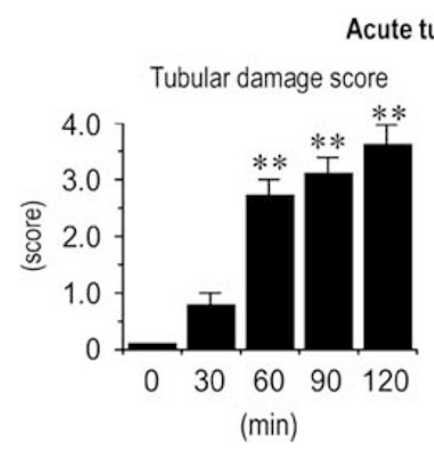

Acute tubular injury (ATI)
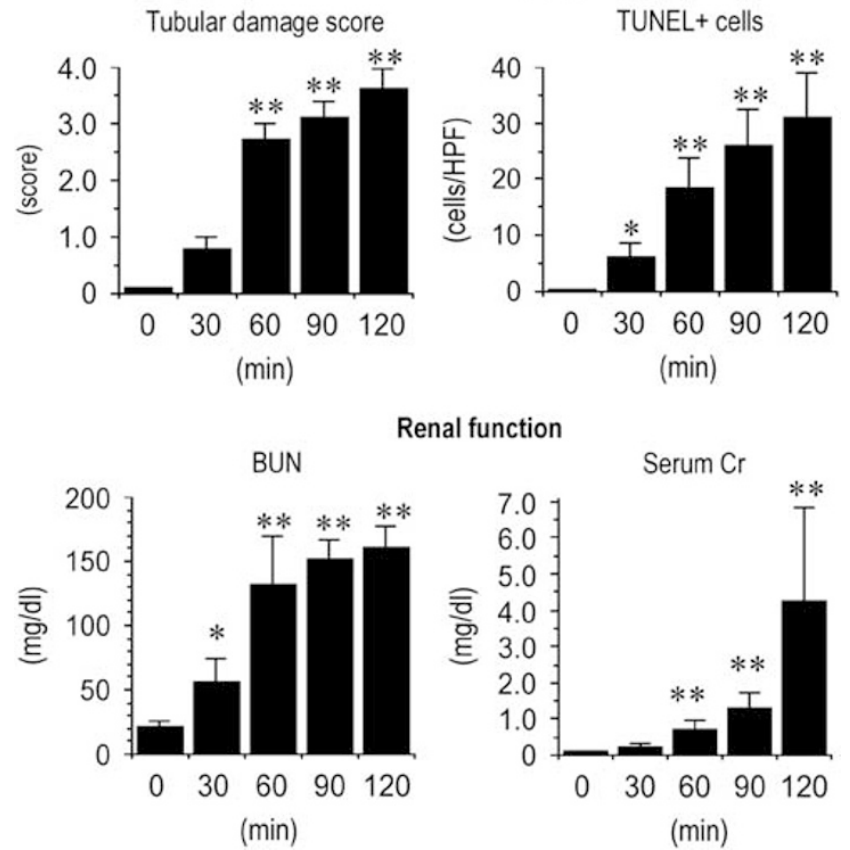

Renal function

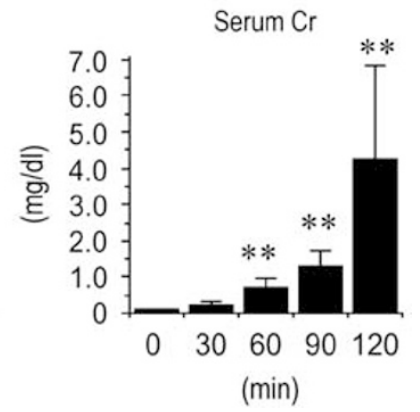

Figure 2 The severity of acute tubular injury (ATI) and renal function at $24 \mathrm{~h}$ after 30,60,90, and $120 \mathrm{~min}$ ischemia. The score of tubular damage and the number of TUNEL + dead cells increased at $24 \mathrm{~h}$ after ischemiareperfusion. Serum creatinine $(\mathrm{Cr})$ and blood urea nitrogen (BUN) also increased at $24 \mathrm{~h}$ after ischemia-reperfusion. ATI and renal dysfunction at $24 \mathrm{~h}$ after reperfusion developed depending on the duration of ischemia between $30 \mathrm{~min}$ and $120 \mathrm{~min}$. Data are mean \pm s.d. of $n=5$ mice. ${ }^{*} P<0.05$; ${ }^{*} * P<0.01$.

cells was evident with flattened regenerating epithelial cells, especially in the straight portion of the proximal tubules in the outer medulla of the kidney of the mice with more than $60 \mathrm{~min}$ ischemia. In addition to the necrotic epithelial cells, apoptotic tubular epithelial cells were also present, indicated by TUNEL staining. ATI was maximal at $24 \mathrm{~h}$ after reperfusion, and renal dysfunction developed at $24 \mathrm{~h}$ (Figure 2). The severity of ATI, which was examined by tubular damaged score and the number of TUNEL + tubular epithelial cells, and the renal dysfunction developed depending on the duration of ischemia between $30 \mathrm{~min}$ and $120 \mathrm{~min}$.

We also analyzed MMP-2 and MMP-9 activity in the renal cortex using gelatin zymography (Figure 3). Ischemia-reperfusion resulted in increased MMP-2 and MMP-9 activity in MMP- $2^{+1+}$ mice from the early period after reperfusion (at least $2 \mathrm{~h}$ ). After reperfusion, the activity of both MMP-2 and MMP-9 increased and reached peak levels at $6 \mathrm{~h}$. Subsequently, both activities gradually decreased but were still present at $24 \mathrm{~h}$ after reperfusion. The increase of MMP-2 and MMP-9 activities after reperfusion seemed to be dependent on the duration of ischemia between $30 \mathrm{~min}$ and $120 \mathrm{~min}$.

Next, we examined the expression of MMP-2, TIMP-1, and TIMP-2 in renal tissues from before ischemia and $6 \mathrm{~h}$ after reperfusion when MMP-2 activity was the highest during the experiment according to the results of gelatin zymography. a

a (30 min ischemia)

after reperfusion

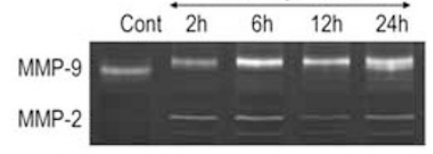

(60 min ischemia) after reperfusion

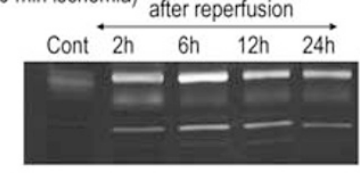

(90 min ischemia)

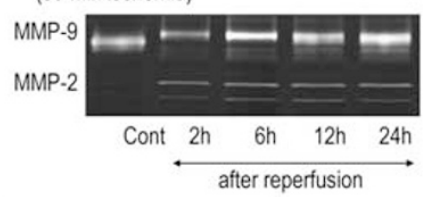

(120 min ischemia)

b
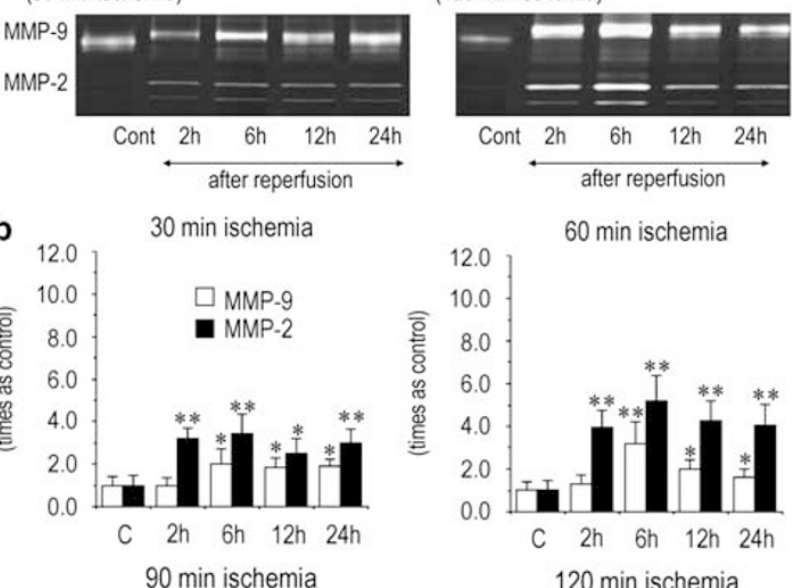

$60 \mathrm{~min}$ ischemia

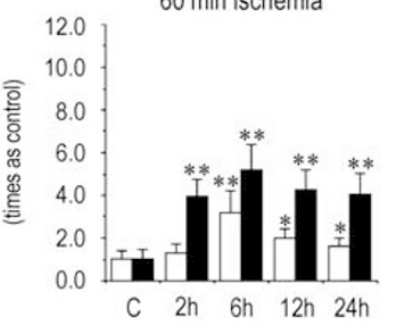

$120 \mathrm{~min}$ ischemia
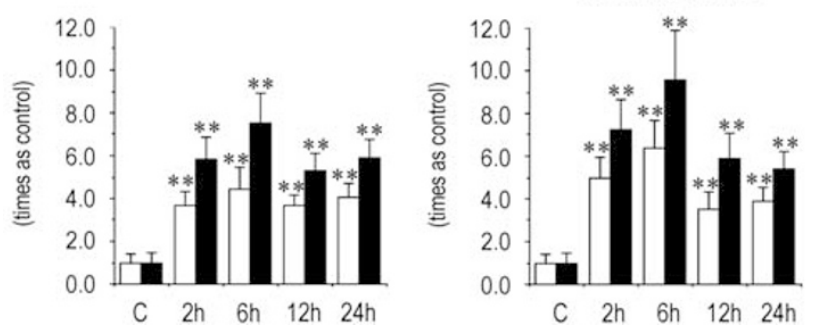

Figure 3 MMP-2 and MMP-9 activities during ischemia-reperfusion injury after 30, 60, 90, and 120 min ischemia. (a) Representative gelatin zymography examples of five experiments during the development of ATI following $24 \mathrm{~h}$ after 30, 60, 90, and 120 min ischemia. (b) Quanititative data of MMP-2 and MMP-9 activities during the development of ATI following $24 \mathrm{~h}$ after $30,60,90$, and $120 \mathrm{~min}$ ischemia. Data are mean \pm s.d. of $n=5$ mice. ${ }^{\star} P<0.05 ;{ }^{*} P<0.01$. In gelatin zymography, MMP-2 and MMP-9 activities increased in injured kidney at $2 \mathrm{~h}$ after ischemia-reperfusion, reached its highest level at $6 \mathrm{~h}$, before the full development of ATI. The activities gradually decreased thereafter. MMP-2 and MMP-9 activities at $6 \mathrm{~h}$ after reperfusion increased depending on the duration of ischemia between $30 \mathrm{~min}$ and $120 \mathrm{~min}$.

At baseline, MMP-2 was negative in the outer medulla, whereas TIMP-1 and TIMP-2 were expressed on tubular epithelial cells (Figure 4). However, at $6 \mathrm{~h}$ after reperfusion, the expression of MMP-2 increased, and the expression of TIMP-1 and TIMP-2 decreased. MMP-2 was expressed on cells in the interstitium around tubules. Especially, doubleimmunostaining for MMP-2 and Tomato Lectin showed MMP-2 expression on endothelial cells in peritubular capillaries (PTCs) and cells in the interstitial areas around PTCs (probably pericytes or fibrocytes) (Figure 5). Examination of MMP-2 and MMP-9 activities by in situ zymography showed gelatinase activity mainly in the interstitium around tubules (probably PTCs) at $6 \mathrm{~h}$. Moreover, TUNEL staining showed some TUNEL + endothelial cells in PTCs, before the development of tubular epithelial cell injury. In addition, congestion 
MMP-2
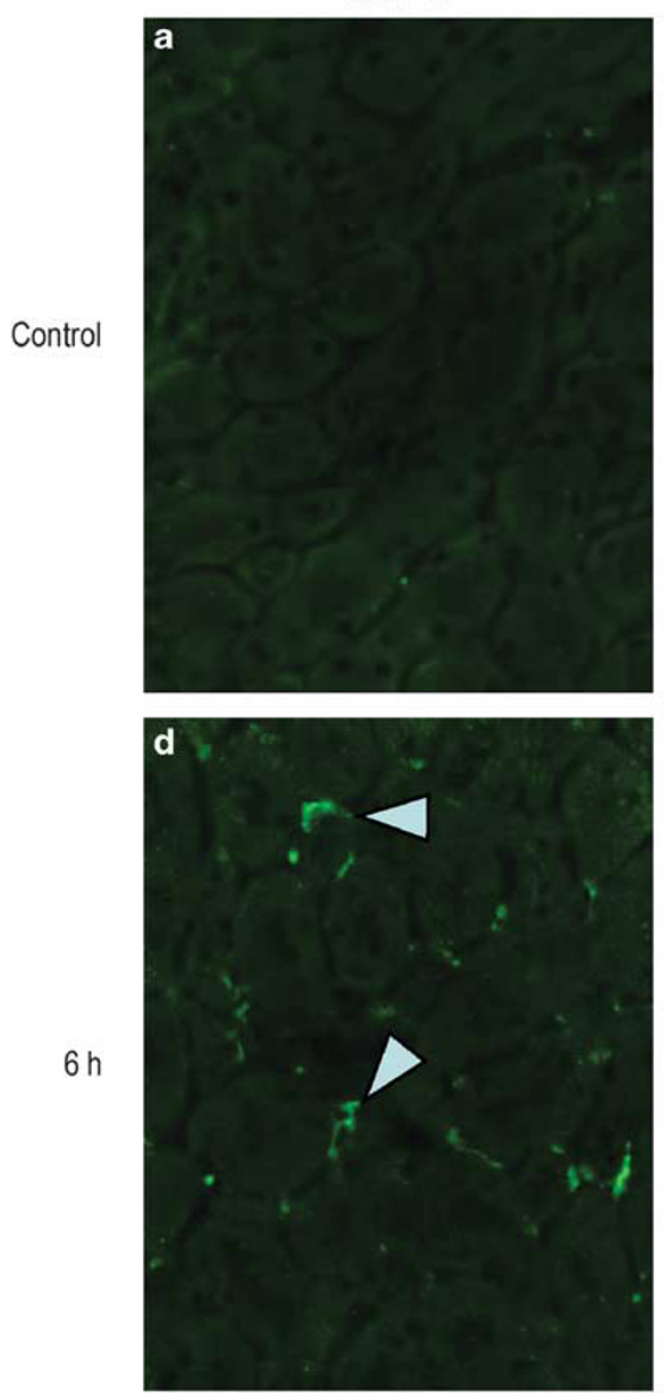

TIMP-1
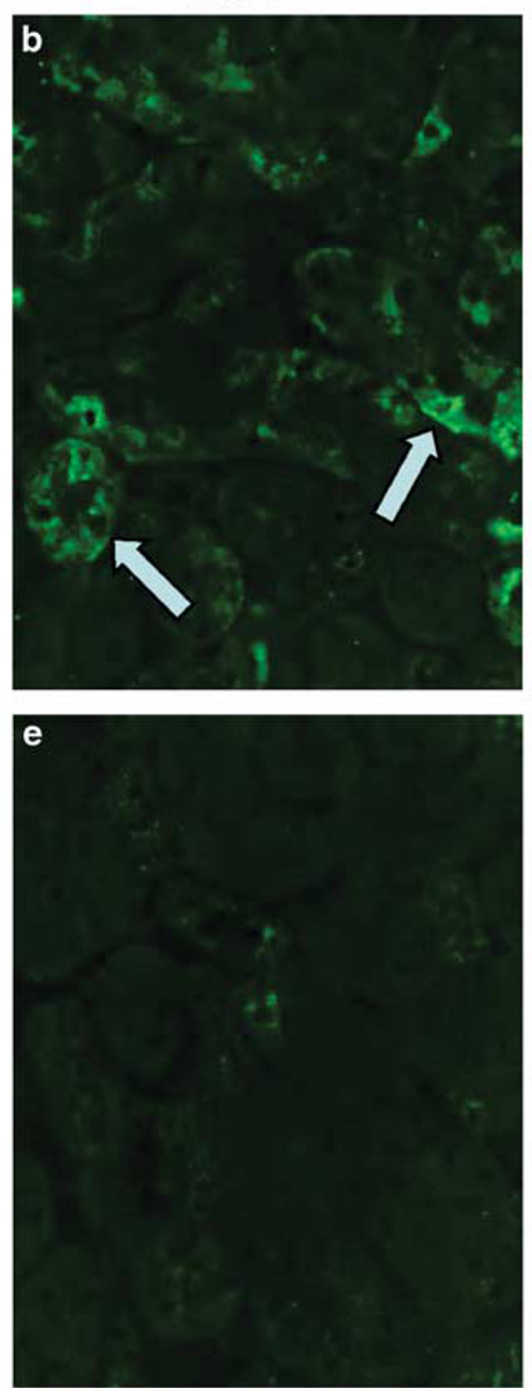

TIMP-2
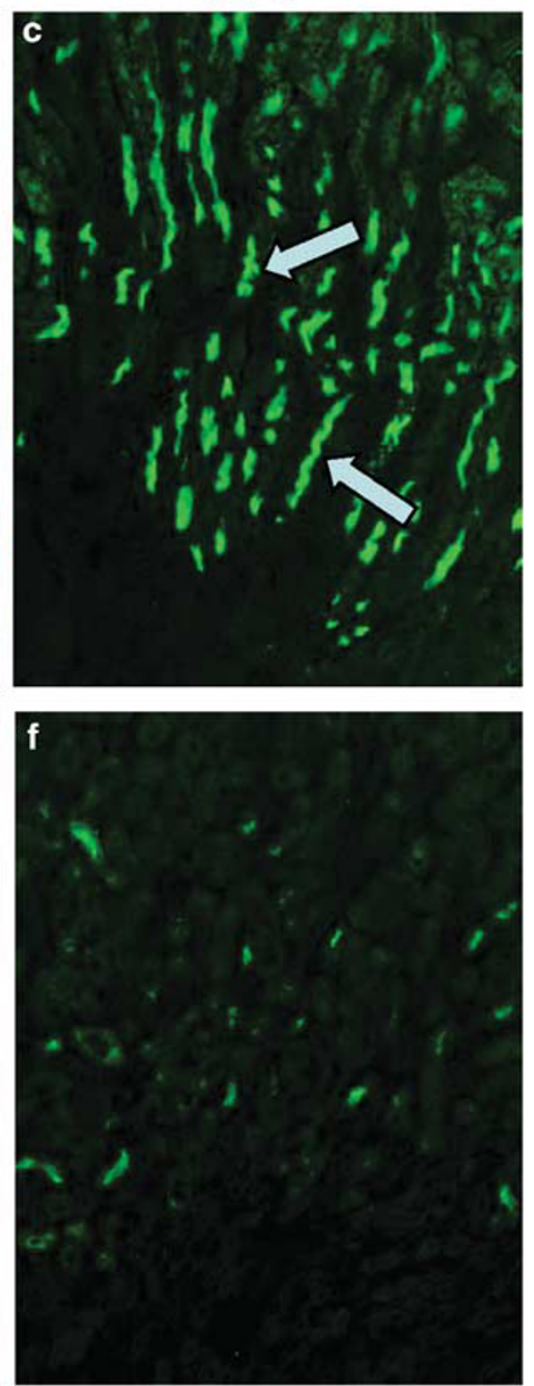

Figure 4 Immunohistochemical analysis of the expression of MMP-2 (a, d: $\times 400)$, TIMP-1 (b, e: $\times 400)$, and TIMP-2 (c, f: $\times 200)$, before ischemia control $(\mathbf{a}-\mathbf{c})$ and $6 \mathrm{~h}(\mathbf{d}-\mathbf{f})$ after $60-\mathrm{min}$ ischemia-reperfusion in MMP-2 ${ }^{+/+}$mice. At $6 \mathrm{~h}$ after ischemia-reperfusion when MMP-2 activities were highest, increased expression of MMP-2 (arrowhead) was evident in the interstitium around renal tubules. In contrast, tubular expression of TIMP-1 (arrow) and TIMP-2 (arrow) was decreased at $6 \mathrm{~h}$ after ischemia-reperfusion.

and interstitial hemorrhage were noted around the renal tubules at $6 \mathrm{~h}$.

Electron microscopic findings showed that PTC injury developed at $6 \mathrm{~h}$ after reperfusion (Figure 6). Before the development of tubular epithelial injury, disruption of the basement membrane was evident in PTCs, resulting in the destruction of PTCs with interstitial edema and hemorrhage. Apoptotic endothelial cells, as well as swollen endothelial cells were noted in PTCs, suggesting apoptotic endothelial cell injury and endothelial cell activation after 60-min ischemia-reperfusion.

\section{Ischemic AKI in MMP-2 ${ }^{-1-}$ Mice}

To clarify the role of MMP-2 in ischemia-reperfusion AKI, 60min ischemia-reperfusion was induced in $\mathrm{MMP}^{-2^{-1-}}$ mice.
The kidneys of MMP-2 ${ }^{-1-}$ mice showed minimal congestion and interstitial hemorrhage (probably associated with mild PTC injury) at $6 \mathrm{~h}$, and mild renal tubular epithelial cell injury with preservation of renal blood urea nitrogen and $\mathrm{Cr}$ levels at $24 \mathrm{~h}$ (Figures 7 and 8). Gelatin zymography confirmed the lack of MMP-2 activity during the experiment (Figure 9). MMP-9 activity increased by $6 \mathrm{~h}$, similar to MMP-2 ${ }^{+/+}$mice. From 6 to $24 \mathrm{~h}$ after reperfusion, MMP-9 activity gradually decreased, but higher expression was evident at $24 \mathrm{~h}$ after reperfusion than pre-ischemic control rats (baseline). Comparison of MMP-2 ${ }^{-1-}$ and MMP-2 $2^{+1+}$ mice showed similar MMP-9 activity at both baseline and $6 \mathrm{~h}$, and no upregulation of MMP-9 in MMP- $2^{-1-}$ mice before and after ischemia, compared with MMP- $2^{+1+}$ mice. 

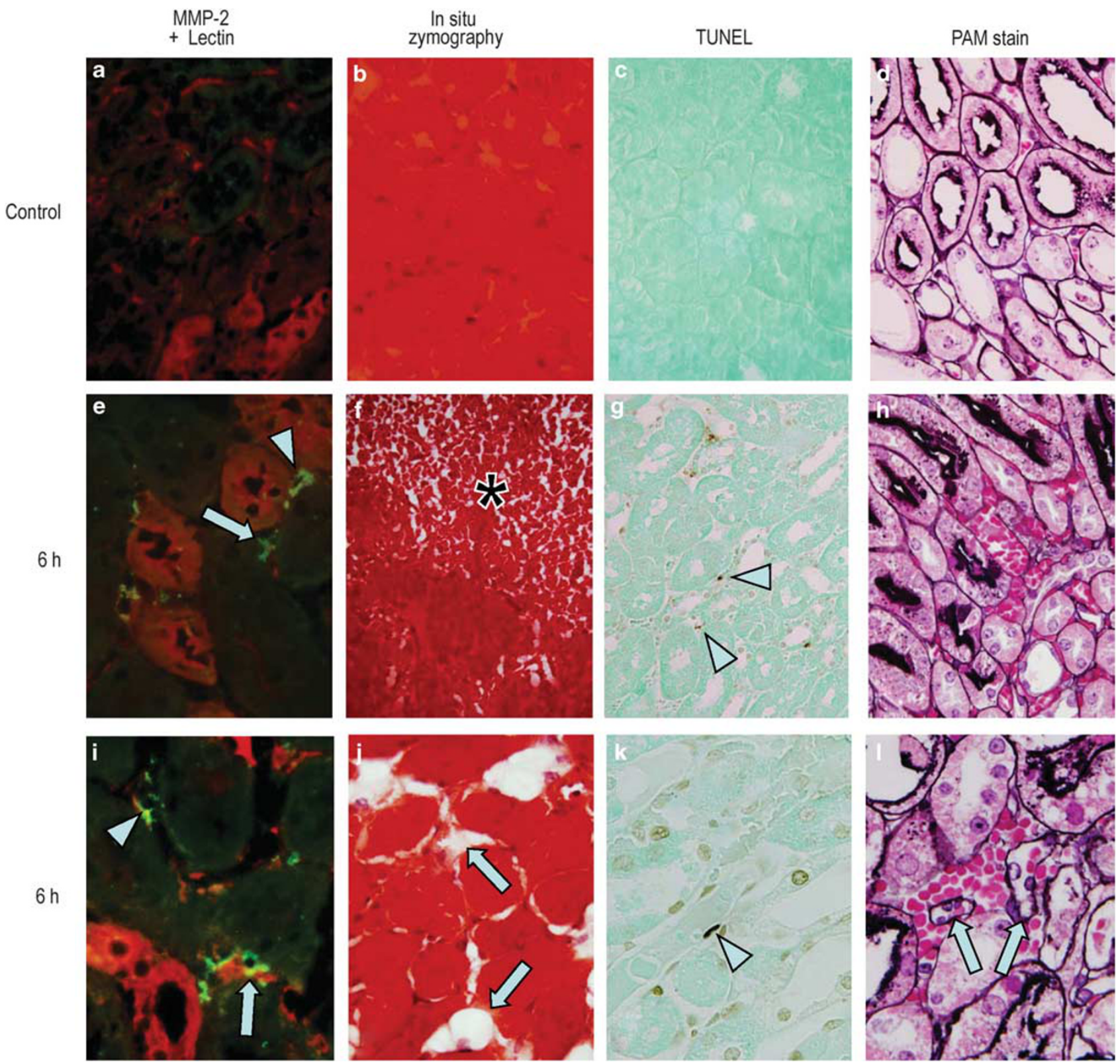

Figure 5 Peritubular capillary (PTC) injury and interstitial hemorrhage before ischemia (control) (a-d) and $6 \mathrm{~h}$ (e-I) after 60-min ischemia-reperfusionin MMP-2 $2^{+/+}$mice. MMP-2 + Lectin (a, e: $\times 600 ;$ i: $\times 800$ ): double immunofluorescence studies of MMP-2 (FITC, green) and Tomato Lectin (Texas-red, red) showed expression of MMP-2 on endothelial cells in PTCs (arrowhead in $\mathbf{e}$, i) and cells present around PTCs (probably pericytes or fibrocytes) (arrow in $\mathbf{e}$, i). In situ zymography $(\mathbf{b}, \mathbf{j}: \times 600 ; \mathbf{f}: \times 100)\left({ }^{*}\right)$ in $(\mathbf{f})$ indicates the outer stripe of outer medulla in kidney. Gelatinase activity was evident in interstitium around tubules including PTCs in the outer medulla at $6 \mathrm{~h}$ after ischemia-reperfusion. TUNEL (c, g: $\times 600 ; \mathbf{k}: \times 800)$ : TUNEL stain identified apoptotic cells with positive nuclear stain in the interstitium around renal tubules at $6 \mathrm{~h}$ after ischemia-reperfusion, before the development of tubular epithelial cell death. High magnification (k) clearly showed the TUNEL + apoptotic endothelial cell in PTC. Periodic acid-methenamine stain (d, h: $\times 600$; I: $\times 800)$ : interstitial hemorrhage around renal tubules at $6 \mathrm{~h}$ after 60 -min ischemia-reperfusion, before the development of tubular epithelial cell necrosis. Arrow in (I) indicates PTCs with large and round endothelial cell nuclei in interstitial hemorrhage.

\section{Ischemic AKI in MMP-2 ${ }^{+I+}$ Mice Treated with Inhibitors of MMPs}

To test the therapeutic effects of MMP inhibitors on ischemic AKI, MMP- $2^{+1+}$ mice subjected to 60 -min ischemia-reperfusion were injected with minocycline or synthetic peptide MMP inhibitor (MMP-2/MMP-9 inhibitor III). Both inhibitors of MMPs reduced congestion and interstitial hemorrhage in the outer medulla in MMP- $2^{+1+}$ mice at $6 \mathrm{~h}$, suggesting that this action is associated with inhibition of PTC injury (Figure 7). Furthermore, the two MMP inhibitors reduced ATI, which was examined by tubular damaged score and the number of TUNEL + tubular epithelial cells, and 

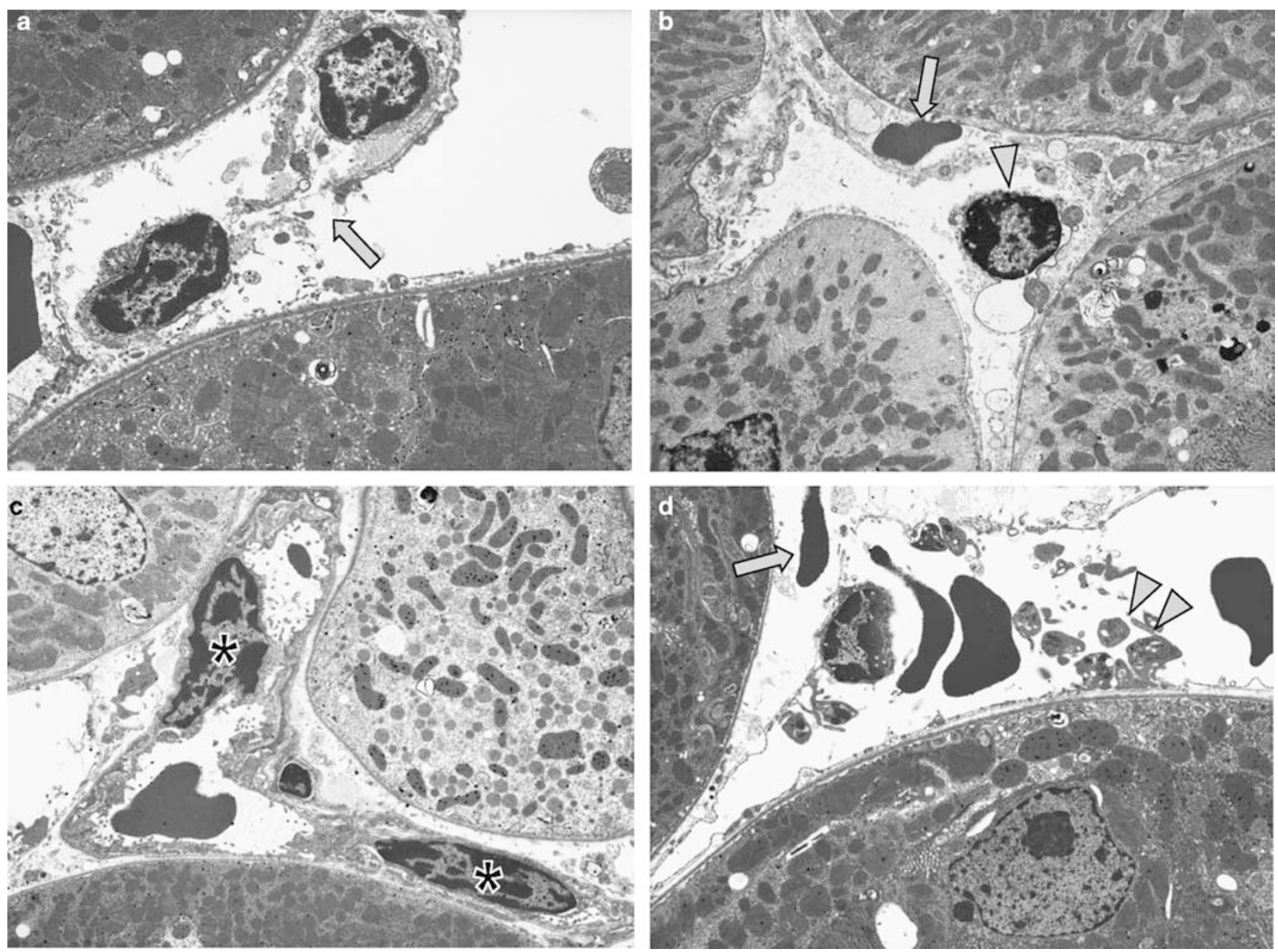

Figure 6 Electron microscopy showing peritubular capillary (PTC) injury at $6 \mathrm{~h}$ after 60 -min ischemia-reperfusion in MMP-2 $2^{+1+}$ mice $(\mathbf{a}$, d: $\times 8,000$; b, c: $\times 4,000$ ). Disruption of the basement membrane (BM) (arrow in a) and destruction of PTCs were noted, together with interstitial edema and hemorrhage. Apoptotic endothelial cells (arrowhead in $\mathbf{b}$ ) and swollen endothelial cells ( ${ }^{*}$ in $\mathbf{c}$ ) were also seen in PTCs with intracapillary accumulation of platelets (arrowhead in d). Exudative red blood cells (arrow in $\mathbf{b}$ and $\mathbf{d}$ ) were present aroud PTCs. Necrosis of tubular epithelial cells did not develop at $6 \mathrm{~h}$ after 60-min ischemia and reperfusion.

improved renal dysfunction at $24 \mathrm{~h}$ (Figures 7 and 8 ). These results suggest that inhibition of MMP-2 and MMP-9 could reduce ischemic AKI by protecting PTCs against injury.

\section{DISCUSSION}

The present studies indicated that renal ischemia-reperfusion results in overexpression of MMP-2 at the site of renal injury (outer medulla). The expression of MMP-2 was detected on endothelial cells and pericytes and interstitial cells within or around the PTCs in the outer medulla. At $6 \mathrm{~h}$ after reperfusion when the activity of MMP-2 and MMP-9 was most increased during the experiment, destruction of PTCs developed with disruption of basement membrane of PTCs and interstitial hemorrhage. Subsequently, tubular epithelial cell injury, including apoptosis and necrosis developed in the outer medulla with renal dysfunction by $24 \mathrm{~h}$. On the other hand, the kidneys of MMP- $2^{-1-}$ mice, or mice treated with minocycline or inhibitor of MMP-2 and MMP-9 showed minimal PTC injury and subsequent suppression of ATI with preservation of renal function by $24 \mathrm{~h}$. Considered together, these findings indicate that overexpression of MMPs, especially MMP- 2 mediated the degradation of basement membrane of PTCs and subsequent destruction of PTCs with interstitial hemorrhage, which could be associated with the development of severe ATI. Thus, MMP-2 and MMP-9 have a deleterious effect in ischemia-reperfusion AKI, and their inhibition protect against acute phase of AKI. The results also point to a potential therapeutic target for the development of new pharmacological agents aimed at reducing AKI.

There is a general agreement that MMPs have a pathologic role in ischemic organ failure by degrading ECM substrates that are essential for normal signalling and homeostasis within the ischemic site. ${ }^{13-15}$ After the onset of ischemic-reperfusion, uncontrolled MMP activity is reported to mediate aberrant proteolysis thus leading to microvascular dysfunction and cell death. ${ }^{22,36}$ Many groups have demonstrated that MMPs, 

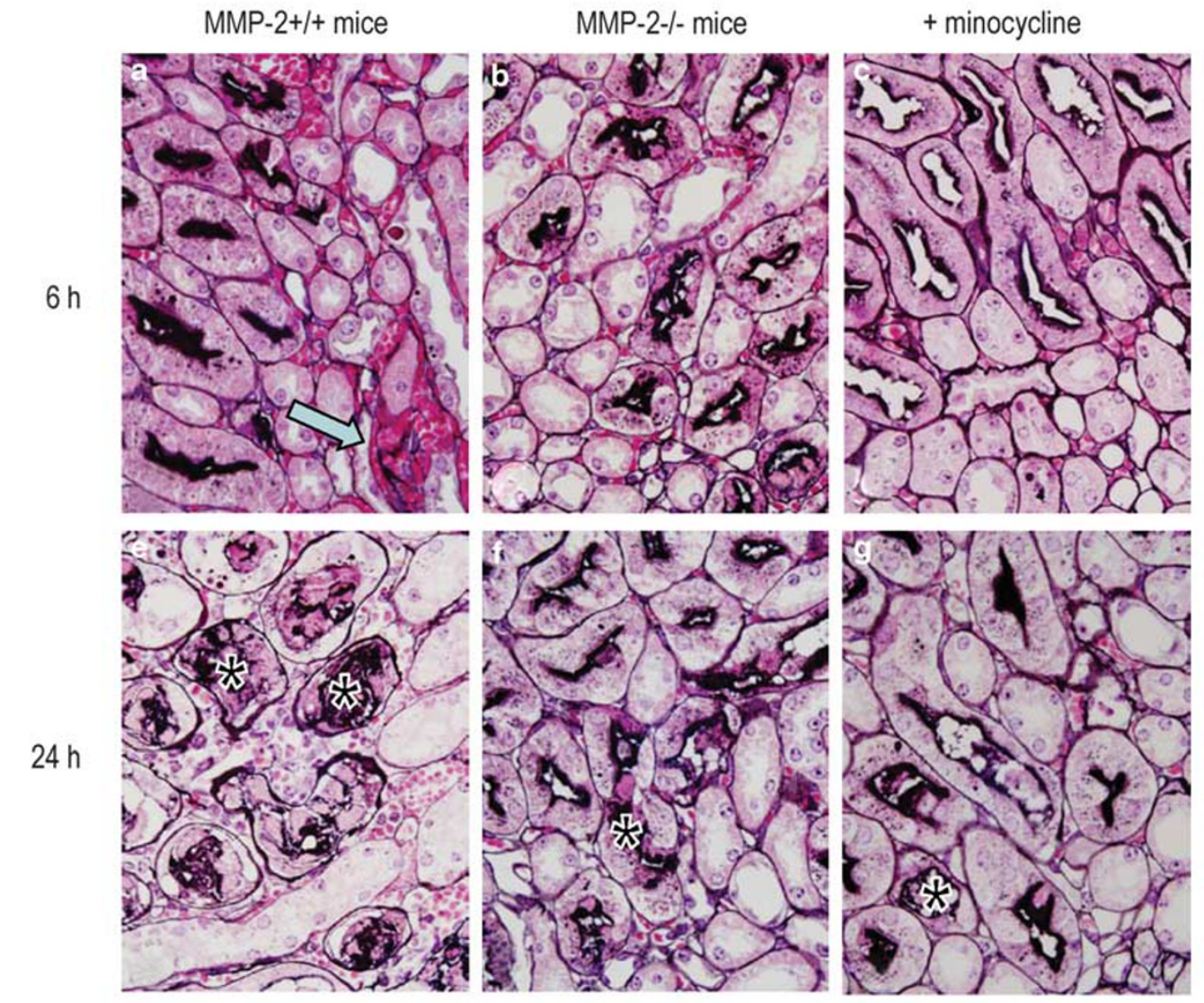

+ MMP-2/MMP-9 inhibitor III
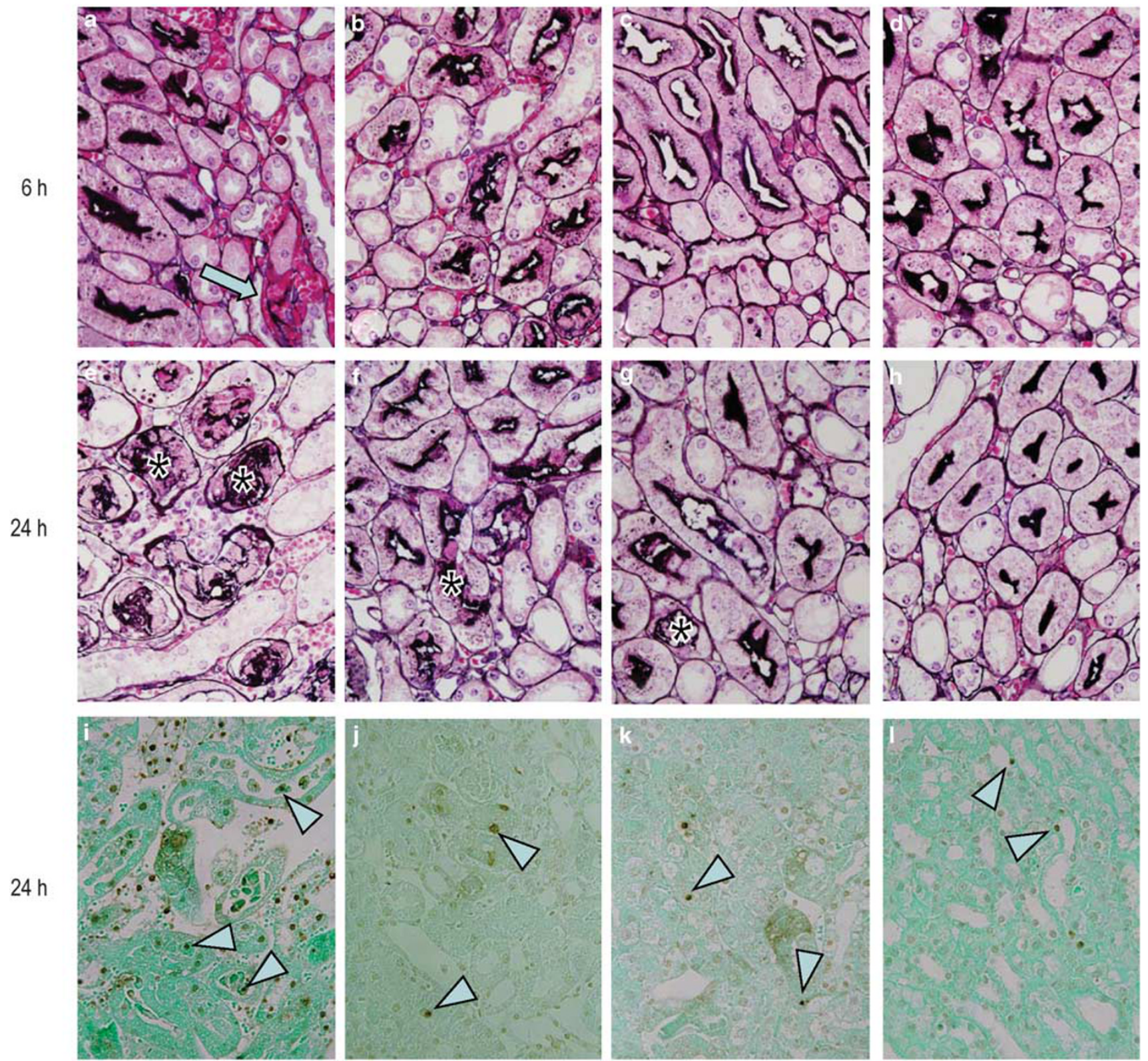

Figure 7 Interstitial hemorrhage at $6 \mathrm{~h}(\mathbf{a}-\mathbf{d})$ and acute tubular injury (AKI) at $24 \mathrm{~h}(\mathbf{e}-\mathbf{l})$ after 60 -min ischemia-reperfusion in $\mathrm{MMP}-2^{+/+}$mice $(\mathbf{a}, \mathbf{e}, \mathbf{i})$, MMP- $2^{-/-}$mice $(\mathbf{b}, \mathbf{f}, \mathbf{j})$, and MMP-2 ${ }^{+/+}$mice treated with inhibitor of MMPs, minocycline $(\mathbf{c}, \mathbf{g}, \mathbf{k})$ and synthetic peptide (MMP-2/MMP-9 inhibitor III) (d, $\mathbf{h}, \mathbf{l}$ ) (a-h: periodic acid-methenamine stain, $\times 600$; i-I: TUNEL stain, $\times 400)$. Congestion of peritubular capillaries and interstitial hemorrhage at $6 \mathrm{~h}$ and ATI including TUNEL + apoptotic cells (arrowhead in $\mathbf{i}$ to $\mathbf{l}$ ) at $24 \mathrm{~h}$ were diminished in MMP-2 $2^{-/-}$mice and MMP- $2^{+/+}$mice treated with MMP inhibitors, compared with MMP-2 ${ }^{+/+}$mice.

especially MMP-2 and MMP-9, rapidly increase in cerebral, heart, liver, lung, and other tissues after ischemia or ischemiareperfusion in experimental animals. ${ }^{13-20}$

Renal ischemia or ischemia-reperfusion is also reported to increase MMP-2 and MMP-9 protein levels or activities. ${ }^{21-24}$ Overexpression of MMP-2 and MMP-9 is localized to the interstitium or tubulointerstitium, and may have an important role in renal microvascular injury with leakage of higher molecular weight substances and capillary loss after ischemia. ${ }^{22}$ In the present study, the expression of MMP-2 and MMP-9 was detected much earlier, at least $2 \mathrm{~h}$ after reperfusion and MMP-2 appeared to stain with endothelial cells in PTCs and interstitial cells. When the activities of MMP-2 and MMP-9 reached peak levels at $6 \mathrm{~h}$ after reperfusion, before the full development of tubular epithelial cell injury, disruption of the basement membrane of PTCs was noted with endothelial cell death and interstitial edema and hemorrhage, indicating that renal microvascular 
Acute tubular injury (ATI)
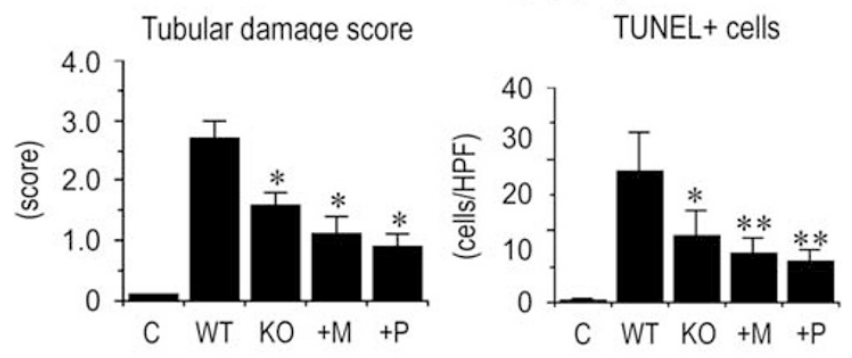

Renal function
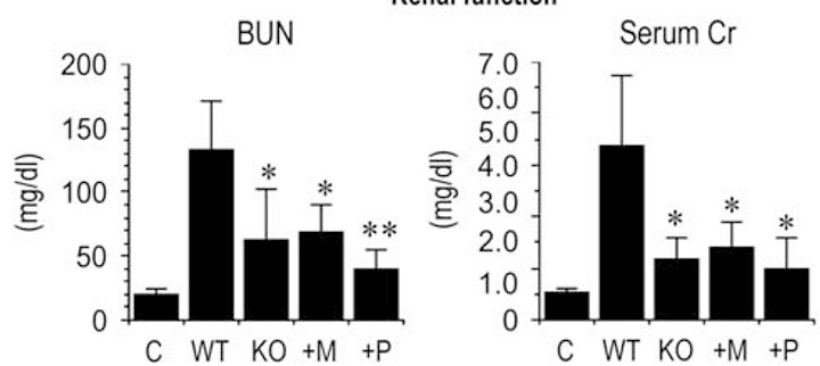

Figure 8 The severity of acute tubular injury (ATI) and renal function before ischemia (C) and $24 \mathrm{~h}$ after $60 \mathrm{~min}$ ischemia in $\mathrm{MMP}-2^{+/+}$mice $(\mathrm{WT}), \mathrm{MMP}^{-2^{-1-}}$ mice $(\mathrm{KO}), \mathrm{MMP}^{+1+} \mathrm{2}^{++}$mice treated with inhibitors of MMPs, minocycline $(+M)$ and synthetic MMP-2/MMP-9 inhibitor $(+P)$. The development of ATI, which was determined by tubular damage score and TUNEL + tubular epithelial cells at $24 \mathrm{~h}$ after reperfusion, was inhibited in $\mathrm{MMP}^{-2^{-1}}$ mice or by the treatment of minocycline and synthetic MMP-2/MMP-9 inhibitor. Renal dysfunction (BUN and serum $\mathrm{Cr}$ ) at $24 \mathrm{~h}$ after reperfusion was also prevented in MMP $-2^{-1-}$ mice or by the treatment of minocycline and synthetic MMP-2/MMP-9 inhibitor. The degree of tubular damage score, the number of TUNEL + tubular epithelial cells, and levels of serum $\mathrm{Cr}$ and BUN seemed to be lower in both MMP inhibitors than in MMP- $2^{-1-}$ mice. Data are mean \pm s.d. of $n=5$ mice per group. ${ }^{*} P<0.05,{ }^{* *} P<0.01$.

destruction developed in the outer medulla, before the full progression of ATI.

In stroke, MMPs are rapidly upregulated after cerebral ischemia in animal models and patients. ${ }^{13,36,37}$ By degrading the neurovascular matrix, MMPs could explain the bloodbrain barrier leakage, edema and hemorrhage. ${ }^{36}$ By disrupting cell-matrix homeostasis, MMPs may trigger cell death. ${ }^{38,39}$ Similarly, the present study demonstrated that, in the development of ischemic ATI, MMP-2, and MMP-9 may have an important role in renal microvascular destruction, and may contribute to the development of tubular epithelial cell death and renal dysfunction. Although MMP-2 and MMP-9 could contribute to disease progression, an important role for MMP-9 in particular has been suggested in ischemic injury of several organs. ${ }^{13-15,36,37}$ In patients with AKI, MMP-9 is a useful urinary biomarker for the early diagnosis of AKI. ${ }^{40}$ MMP- $9^{-/-}$mice and animals treated with MMP-9 inhibitors are protected against ischemia-reperfusion injury in several organs. ${ }^{13-15,36,37,41-44}$ However, MMP-2 has an important role in the development of ischemic ATI, because prevention of PTC destruction and renal dysfunction after ischemia-reperfusion were evident in $\mathrm{MMP}^{-2^{-I}}$ mice in the present study. Furthermore, in AKI, one recent a

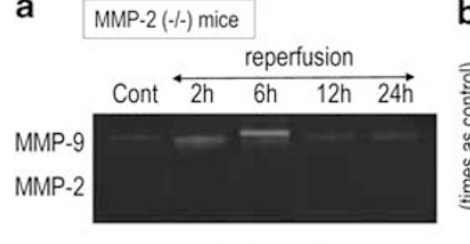

c

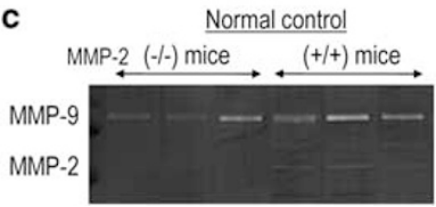

b

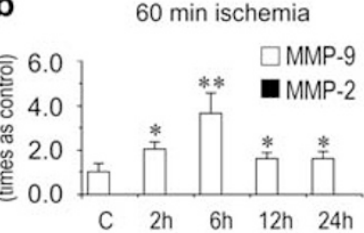

d 6 hrs reperfusion

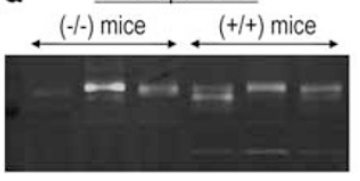

Figure 9 MMP-2 and MMP-9 activities in gelatin zymography in MMP-2 ${ }^{-/-}$ mice. (a) Representative gelatin zymography examples of five experiments during the development of ATI in MMP-2 ${ }^{-1-}$ mice following $24 \mathrm{~h}$ after $60 \mathrm{~min}$ ischemia. (b) Quanititative data of MMP-2 and MMP-9 activities during the development of ATI following $24 \mathrm{~h}$ after $60 \mathrm{~min}$ ischemia. Data are mean \pm s.d. of $n=5$ mice. ${ }^{*} P<0.05 ;{ }^{*} P<0.01$. (c, d) Representative gelatin zymography examples of three experiments each in MMP- $2^{-1-}$ and MMP- $2^{+/+}$mice at preischemia baseline (c) and at $6 \mathrm{~h}$ (d) after $60 \mathrm{~min}$ ischemia. Gelatin zymography using tissues of MMP-2 ${ }^{-1-}$ mice showed no MMP-2 activity during the experiment. MMP-9 activity increased at $6 \mathrm{~h}$ in these mice, similar to MMP- $2^{+/+}$mice. MMP-9 activity gradually decreased at 12 and $24 \mathrm{~h}$ after reperfusion. MMP-9 activity was similar in $\mathrm{MMP}^{-2^{-1-}}$ and MMP-2 ${ }^{+/+}$mice at baseline and at $6 \mathrm{~h}$ after 60 -min ischemia-reperfusion.

study indicated that overexpression of MMP-9 after folic acid injection or 45-min ischemia-reperfusion protected renal tubules against apoptosis, and severe ATI developed in MMP- $9^{-1-}$ mice. ${ }^{27}$ Therefore, in AKI, MMP-2 may have a more strong influence than MMP-9 on the development of ischemic AKI, although, in the present study, the ameliorative effects of inhibitors of both MMP-2 and MMP-9 on the severity of ATI were more pronounced than those of MMP-2 ${ }^{-1-}$ mice. MMP-2 was expressed on endothelial cells and pericytes or interstitial cells within or around PTCs. In several organs, the most abundant source of MMP-9 is infiltrating neutrophils. ${ }^{36,37,45}$ However, in AKI at $6 \mathrm{~h}$ after reperfusion, at the time of peak activity of MMP-9, only few neutrophils had infiltrated at the site of renal injury (data not shown).

The function of MMPs is also regulated by enzyme inhibitors. The endogenous inhibitors of MMP-9 and MMP-2, are TIMPs, with TIMP-1 being more selective for MMP-9, and TIMP-2 being more selective for MMP-2. ${ }^{11,12}$ In diseases characterized by profound matrix degradation, the balance between MMPs and TIMPs is often offset, resulting in an overall net increase in MMP activity. Immunohistochemical analysis in the present study demonstrated downregulation of TIMP- 1 and TIMP- 2 at $6 \mathrm{~h}$ after reperfusion. Thus, the ischemia-reperfusion-induced MMP expression is expected to shift the protease-protease inhibitor balance toward proteolytic activity and ECM degradation.

To examine the possible use of MMP inhibitor therapy for AKI, ischemic AKI in MMP- $2^{+1+}$ mice was examined further by administering minocycline or MMP-2/MMP-9 inhibitor. The results of this experiment demonstrated that 
MMP-2 and MMP-9 inhibitors significantly reduced the severity of PTC damage, suppressed the development of AKI, and preserved renal function after ischemia-reperfusion, clearly demonstrating the importance of this enzyme in the development of ischemic AKI. Although inhibition of MMP-2 and MMP-9 mitigates the PTC destruction and the development of AKI, our observation does not exclude the possible role of the inflammatory cascade to renal microvascular injury after ischemia. MMP activity is usually linked to inflammation. ${ }^{46-48}$ MMPs participate in complex injury responses through interactions with and activation of cytokines, chemokines and other pericellular, and cell surface substrates, and inhibition would limit the action of these pro-inflammatory agents. Furthermore, minocycline is known for its broad anti-inflammatory actions, in addition to its action as an MMP inhibitor. Indeed, minocycline has been demonstrated to inhibit tubular cell apoptosis, diminish inflammation, and provide an overall protective effect on renal function following ischemia. ${ }^{29}$ Thus, minocycline may function by inhibiting MMPs' activities and/or a number of other mechanisms.

In the present study, ischemia-reperfusion renal injury resulted in overexpression of MMPs, especially MMP-2 at the site of injury in the kidney. The development of ischemic AKI was associated with upregulation of MMPs, which subsequently mediated acute microvascular disruption and progression of ATI. Data from MMP- $2^{-1-}$ mice and pharmacological experiments suggest that MMP-2 and MMP-9 may be attractive therapeutic targets for ischemic AKI. However, our results in the present study contradicts with findings of the other studies, which states that MMP-2 is elevated in late (8 weeks) post-ischemia-reperfusion injury, ${ }^{25}$ that renal MMP activity is unaffected by ischemia-reperfusion, or that inhibition of MMPs does not alter the outcome of renal function. ${ }^{26}$ We assume these discrepancies may be related to the animal/strain used, and moreover the severity of injury/length of ischemia used in the studies held by us and the studies done by them. We are therefore planning on doing a pre-clinical study using non-human primates to test the effects of MMP inhibition on AKI. Accumulating evidence also suggests that MMPs may have beneficial roles during remodeling and/or recovery from the several diseases and organ injuries, including ischemia-reperfusion. ${ }^{13,37,49,50}$ We are therefore now examining the roles of MMP-2 and MMP-9, and the influences of inhibitors of these MMPs, in the recovery from ischemic AKI.

\section{ACKNOWLEDGEMENT}

This study was supported by Japan Society for the Promotion of Science, Grant-in-Aid for Scientific Research (C18591787 and C20591900).

\section{DISCLOSURE/CONFLICT OF INTEREST}

The authors declare no conflict of interest.

1. Siegel NJ, Shah SV. Acute renal failure: directions for the next decade J Am Soc Nephrol 2003;14:2176-2177.
2. Schrier RW, Wang W, Poole B, et al. Acute renal failure: definitions, diagnosis, pathogenesis, and therapy. J Clin Invest 2004;114:5-14.

3. Versteilen AM, Di Maggio F, Leemreis JR, et al. Molecular mechanisms of acute renal failure following ischemia/reperfusion. Int J Artif Organs 2004;27:1019-1029.

4. Lameire N, Van Biesen W, Vanholder R. Acute renal failure. Lancet 2005;365:417-430.

5. Chertow GM, Burdick E, Honour M, et al. Acute kidney injury, mortality, length of stay, and costs in hospitalized patients. J Am Soc Nephrol 2005;16:3365-3370.

6. Lieberthal W, Nigam SK. Acute renal failure. II. Experimental models of acute renal failure: imperfect but indispensable. Am J Physiol Renal Physiol 2000;278:F1-F12.

7. Bonventre JV, Weinberg JM. Recent advances in the pathophysiology of ischemic acute renal failure. J Am Soc Nephrol 2003;14:2199-2210.

8. Devarajan P. Update on mechanisms of ischemic acute kidney injury. J Am Soc Nephrol 2006;17:1503-1520.

9. Sutton TA, Fisher CJ, Molitoris BA. Microvascular endothelial injury and dysfunction during ischemic acute renal failure. Kidney Int 2002;62: 1539-1549.

10. Molitoris BA, Sutton TA. Endothelial injury and dysfunction: role in the extension phase of acute renal failure. Kidney Int 2004;66:496-499.

11. Egeblad M, Werb Z. New functions for the matrix metalloproteinases in cancer progression. Nat Rev Cancer 2002;2:161-174.

12. Nagase $H$, Visse $R$, Murphy $G$. Structure and function of matrix metalloproteinases and TIMPs. Cardiovasc Res 2006;69:562-573.

13. Rosell A, Lo EH. Multiphasic roles for matrix metalloproteinases after stroke. Curr Opin Pharmacol 2008;8:82-89.

14. Chow AK, Cena J, Schulz R. Acute actions and novel targets of matrix metalloproteinases in the heart and vasculature. $\mathrm{Br} J$ Pharmacol 2007;152:189-205.

15. Janssens S, Lijnen HR. What has been learned about the cardiovascular effects of matrix metalloproteinases from mouse models? Cardiovasc Res 2006;69:585-594.

16. Viappiani S, Sariahmetoglu M, Schulz R. The role of matrix metalloproteinase inhibitors in ischemia-reperfusion injury in the liver. Curr Pharm Des 2006;12:2923-2934.

17. Soccal PM, Gasche Y, Miniati DN, et al. Matrix metalloproteinase inhibition decreases ischemia-reperfusion injury after lung transplantation. Am J Transplant 2004:4:41-50.

18. Mathalone $\mathrm{N}$, Lahat $\mathrm{N}$, Rahat $\mathrm{MA}$, et al. The involvement of matrix metalloproteinases 2 and 9 in rat retinal ischemia. Graefes Arch Clin Exp Ophthalmol 2007;245:725-732.

19. Roach DM, Fitridge RA, Laws PE, et al. Up-regulation of MMP-2 and MMP-9 leads to degradation of type IV collagen during skeletal muscle reperfusion injury; protection by the MMP inhibitor, doxycycline. Eur J Vasc Endovasc Surg 2002;23:260-269.

20. Muhs BE, Plitas $G$, Delgado $Y$, et al. Temporal expression and activation of matrix metalloproteinases-2, -9, and membrane type 1-matrix metalloproteinase following acute hindlimb ischemia. J Surg Res 2003;111:8-15.

21. Basile DP, Fredrich $\mathrm{K}$, Weihrauch $\mathrm{D}$, et al. Angiostatin and matrix metalloprotease expression following ischemic acute renal failure. Am J Physiol Renal Physiol 2004;286:F893-F902.

22. Sutton TA, Kelly $\mathrm{KJ}$, Mang $\mathrm{HE}$, et al. Minocycline reduces renal microvascular leakage in a rat model of ischemic renal injury. Am J Physiol Renal Physiol 2005;288:F91-F97.

23. Caron A, Desrosiers RR, Béliveau R. Ischemia injury alters endothelial cell properties of kidney cortex: stimulation of MMP-9. Exp Cell Res 2005;310:105-116.

24. Catania JM, Chen G, Parrish AR. Role of matrix metalloproteinases in renal pathophysiologies. Am J Physiol Renal Physiol 2007;292: F905-F911.

25. Jain S, Bicknell GR, Nicholson ML. Molecular changes in extracellular matrix turnover after renal ischaemia-reperfusion injury. $\mathrm{Br} J$ Surg 2000:87:1188-1192.

26. Ziswiler R, Daniel C, Franz $\mathrm{E}$, et al. Renal matrix metalloproteinase activity is unaffected by experimental ischemia-reperfusion injury and matrix metalloproteinase inhibition does not alter outcome of renal function. Exp Nephrol 2001;9:118-124.

27. Bengatta S, Arnould C, Letavernier E, et al. MMP9 and SCF protect from apoptosis in acute kidney injury. J Am Soc Nephrol 2009;20: 787-797. 
28. Itoh $\mathrm{T}$, Ikeda $\mathrm{T}$, Gomi $\mathrm{H}$, et al. Unaltered secretion of beta-amyloid precursor protein in gelatinase A (matrix metalloproteinase 2)deficient mice. J Biol Chem 1997;272:22389-22392.

29. Kelly KJ, Sutton TA, Weathered N, et al. Minocycline inhibits apoptosis and inflammation in a rat model of ischemic renal injury. Am J Physiol Renal Physiol 2004;287:F760-F766.

30. Koivunen E, Arap W, Valtanen $\mathrm{H}$, et al. Tumor targeting with a selective gelatinase inhibitor. Nat Biotechnol 1999;17: 768-774.

31. Henderson JA, He X, Jabbari E. Concurrent differentiation of marrow stromal cells to osteogenic and vasculogenic lineages. Macromol Biosci 2008;8:499-507.

32. Hentschel $\mathrm{H}$, Walther $\mathrm{P}$. Heterogenous distribution of glycoconjugates in the kidney of dogfish Scyliorhinus caniculus (L.) with reference to changes in the glycosylation pattern during ontogenetic development of the nephron. Anat Rec 1993;235:21-32.

33. Shimizu A, Masuda $Y$, Kitamura $H$, et al. Complement-mediated killing of mesangial cells in experimental glomerulonephritis: cell death by a combination of apoptosis and necrosis. Nephron 2000; 86:152-160.

34. Brooks C, Wei Q, Cho SG, et al. Regulation of mitochondrial dynamics in acute kidney injury in cell culture and rodent models. J Clin Invest 2009;119:1275-1285.

35. Kunugi $S$, Fukuda $\mathrm{Y}$, Ishizaki $\mathrm{M}$, et al. Role of MMP-2 in alveolar epithelial cell repair after bleomycin administration in rabbits. Lab Invest 2001;81:1309-1318.

36. Zhao BQ, Tejima E, Lo EH. Neurovascular proteases in brain injury, hemorrhage and remodeling after stroke. Stroke 2007 38(2 Suppl):748-752.

37. Cunningham LA, Wetzel M, Rosenberg GA. Multiple roles for MMPs and TIMPs in cerebral ischemia. Glia 2005;50:329-339.

38. Gu Z, Kaul M, Yan B, et al. S-nitrosylation of matrix metalloproteinases: signaling pathway to neuronal cell death. Science 2002;297: 1186-1190.
39. Lee SR, Lo EH. Induction of caspase-mediated cell death by matrix metalloproteinases in cerebral endothelial cells after hypoxiareoxygenation. J Cereb Blood Flow Metab 2004;24:720-727.

40. Han WK, Waikar SS, Johnson A, et al. Urinary biomarkers in the early diagnosis of acute kidney injury. Kidney Int 2008;73:863-869.

41. Romanic AM, White RF, Arleth AJ, et al. Matrix metalloproteinase expression increases after cerebral focal ischemia in rats: inhibition of matrix metalloproteinase-9 reduces infarct size. Stroke 1998;29:1020-1030.

42. Lindsey M, Wedin K, Brown MD, et al. Matrix-dependent mechanism of neutrophil-mediated release and activation of matrix metalloproteinase 9 in myocardial ischemia/reperfusion. Circulation 2001;103: 2181-2187.

43. Romanic AM, Harrison SM, Bao W, et al. Myocardial protection from ischemia/reperfusion injury by targeted deletion of matrix metalloproteinase-9. Cardiovasc Res 2002;54:549-558.

44. Hamada T, Fondevila C, Busuttil RW, et al. Metalloproteinase-9 deficiency protects against hepatic ischemia/reperfusion injury. Hepatology 2008;47:186-198.

45. Rosell A, Cuadrado E, Ortega-Aznar A, et al. MMP-9-positive neutrophil infiltration is associated to blood-brain barrier breakdown and basal lamina type IV collagen degradation during hemorrhagic transformation after human ischemic stroke. Stroke 2008;39:1121-1126.

46. Manicone AM, McGuire JK. Matrix metalloproteinases as modulators of inflammation. Semin Cell Dev Biol 2008;19:34-41.

47. Gill SE, Parks WC. Metalloproteinases and their inhibitors: regulators of wound healing. Int J Biochem Cell Biol 2008;40:1334-1347.

48. Korpos E, Wu C, Sorokin L. Multiple roles of the extracellular matrix in inflammation. Curr Pharm Des 2009;15:1349-1357.

49. Fukuda $\mathrm{Y}$, Ishizaki $\mathrm{M}$, Kudoh $\mathrm{S}$, et al. Localization of matrix metalloproteinases-1, -2 and -9 and tissue inhibitor of metalloproteinase- 2 in interstitial lung diseases. Lab Invest 1998;78:687-698.

50. Fukuda $Y$, Ishizaki M, Okada $Y$, et al. Matrix metalloproteinases and tissue inhibitor of metalloproteinases-2 in fetal rabbit lung. Am J Physiol Lung Cell Mol Physiol 2000;279:L555-L561. 